\title{
Biochemical Characterization of Selected Plant Species from Brazilian Savannas
}

\author{
Samantha Salomão Caramori, Claudinei Sousa Lima and Kátia Flávia Fernandes* \\ Laboratório de Química de Proteínas; Universidade Federal de Goiás; Campus Samambaia; katia@icb2.ufg.br; \\ C. P. 131; 74001-970; Goiânia - GO - Brazil
}

\begin{abstract}
The aim of this work was to analyze and quantify the presence of antinutritional compounds such as lectins and trypsin-like inhibitors, polyphenols and tannins, and enzymatic activity of peroxidases and proteases in the seeds of Annona crassiflora Mart. (araticum), Hymenaea courbaril L. var. courbaril (jatobá), Plathymenia reticulata Benth. (vinhático), Zanthoxylum rhoifolium Lam. (maminha de porca), Apeiba tibourbou Aubl. (pau jangada), Salacia crassiflora Mart G. Don. (bacupari), and Sclerolobium paniculatum Vog. (carvoeiro). The results suggested that these plants could be used as new source of food.
\end{abstract}

Key words: Cerrado plants, plant enzymes, biochemical characterization

\section{INTRODUCTION}

The Brazilian savannas, known as "Cerrado", comprise one of the largest biodiversities found in Brazil. The expansion of agricultural areas is causing the extinction of several plant species. Many of the extinct plants could not have appropriate studies of their components, which could have biotechnological applications. Plants from Cerrado are known as source of compounds of high biotechnological interest, which have application on medical and food industries. Plants such as Hymenaea courbaril L. (jatobá) and Myracrodruon urundeuva (aroeira) are reported to treat infections of the urinary and respiratory systems, respectively (Drumond, 1982), and to treat gastric ulcers, rheumatism and hanseniasis. Buriti (Mauritia flexuosa L. f.) and pequi (Caryocar brasiliense Camb.) fruits produce oils with high concentrations of unsatured fatty acids, vitamin $\mathrm{E}$ and substances that block ultraviolet radiation (Almeida et al., 1998). Jatobá has high concentration of protein in its fruits, and it is used to produce flour for cakes, bread and biscuits. Plant proteins such as peroxidases, proteases, lectins and trypsin-like inhibitors have been used in medical and food industries and in the production of kits for laboratorial diagnosis (Henry et al., 1974). The presence of lectins and trypsin-like inhibitors must be analyzed when plant products are consumed. The aim of the present study was to determine and quantify nutrients and antinutritional compounds from seeds of selected plants from Cerrado.

\section{MATERIALS AND METHODS}

\section{Source of material}

Mature seeds of selected plant species (Table 1) were collected from the municipal districts of Goiânia, Jataí and Caldas Novas, state of Goiás,

\footnotetext{
${ }^{*}$ Author for correspondence
} 
Brazil. The seeds were washed in an alcoholic solution followed by immersion in a sodium hypochlorite solution $0.2 \%(\mathrm{v} / \mathrm{v})$ for $5 \mathrm{~min}$. The seeds were divided into two equal portions and one of them was vacuum dried. Both portions were ground and placed in polypropylene recipients hermetically closed and stored in a freezer at $-10^{\circ} \mathrm{C}$.

\section{Elemental analysis}

Elemental analysis was carried out to determine the nutritional potential of the samples, by measuring the amount of ashes, humidity, lipids, proteins and carbohydrates.

Table 1 - Selected plant species.

\begin{tabular}{l|c}
\hline \multicolumn{1}{c|}{ PLANT SPECIES } & POPULAR NAME \\
\hline Annona crassiflora Mart. (Annonaceae) & Araticum \\
Apeiba tibourbou Aubl. (Tiliaceae) & Pau jangada \\
Hymenaea courbaril L. var. courbaril (Leguminosae) & Jatobá \\
Plathymenia reticulata Benth. (Leguminosae) & Vinhático \\
Salacia crassiflora (Mart.) G. Don. (Hippocrateaceae) & Bacupari \\
Sclerolobium paniculatum Vog. (Leguminosae) & Carvoeiro \\
Zanthoxylum rhoifolium Lam. (Rutaceae) & Maminha de porca \\
\hline
\end{tabular}

\section{Extraction and Determination of Soluble Protein}

Samples of ground seeds were diluted in a solution

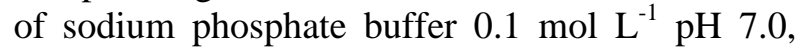
shaken during $1 \mathrm{~h}$ at $4^{\circ} \mathrm{C}$, and then centrifuged at $12,000 \mathrm{x} \mathrm{g}$ for $15 \mathrm{~min}$ at $4^{\circ} \mathrm{C}$. The precipitate was discharged and the supernatant was denominated crude extract. Protein concentration was determined by the method of Bradford (1976), using BSA as standard.

\section{Proteolitic Activity}

Proteolitic activity was determined by incubation of $0.1 \mathrm{~mL}$ of crude extract with $0.5 \mathrm{~mL}$ of casein solution $1 \%(\mathrm{w} / \mathrm{v})$, prepared in phosphate buffer 0.1 mol L ${ }^{-1} \mathrm{pH} 7.6$ at $37^{\circ} \mathrm{C}$ for 20 min. Reaction was terminated by the addition of $1.5 \mathrm{~mL}$ of solution of TCA $5 \%(\mathrm{v} / \mathrm{v})$. After centrifugation at $2,000 \mathrm{x} \mathrm{g}$, the supernatant were read at $280 \mathrm{~nm}$ using a spectrophotometer (Arnon, 1970). One enzyme unit (EU) was defined as the amount of enzyme necessary to produce the elevation of 0.1 in optical density (OD) after $20 \mathrm{~min}$ (Silva et al., 1995).

\section{Protease inhibitor activity}

Samples of crude extract were incubated with 0.1 $\mathrm{mL}$ trypsin solution $1,0 \mathrm{mg} \mathrm{mL}^{-1}$ and phosphate buffer $0.1 \mathrm{~mol} \mathrm{~L}^{-1} \mathrm{pH} 7.6$ at $37^{\circ} \mathrm{C}$ for $10 \mathrm{~min}$. After that $0.5 \mathrm{~mL}$ of a casein solution $1 \%(\mathrm{w} / \mathrm{v})$ was added to the solution and the reaction mixture was incubated for $10 \mathrm{~min}$. The reaction was interrupted by adding of $1.5 \mathrm{~mL}$ of TCA solution $5 \%(\mathrm{v} / \mathrm{v})$ (Arnon, 1970).

\section{Peroxidase activity}

Peroxidase activity was determined according to the methodology of Padiglia et al.. (1995). Reaction was carried out with a solution of ortho-dianizidine $\left(2.2 \mathrm{mmol} \mathrm{L} \mathrm{L}^{-1}\right)$ and $\mathrm{H}_{2} \mathrm{O}_{2}(5$ mmol L${ }^{-1}$ ) in phosphate buffer $0.1 \mathrm{~mol} \mathrm{~L}^{-1} \mathrm{pH} 4.5$, at room temperature $\left(30^{\circ} \mathrm{C}\right)$, and after $1 \mathrm{~min}$, the solution was read at $470 \mathrm{~nm}$ in a spectrophotometer (Ultrospec 2000-Pharmacia). One enzyme unit (EU) was defined as the amount of enzyme necessary to increase 0.1 OD in $1 \mathrm{~min}$ (Padiglia et al., 1995).

\section{Detection of lectins}

The crude extracts $(200 \mu \mathrm{L})$ were mixed with 200 $\mu \mathrm{L}$ of $\mathrm{NaCl}$ solution $\left(0.15 \mathrm{~mol} \mathrm{~L}^{-1}\right)$ containing $\mathrm{CaCl}_{2}\left(0.1 \mathrm{~mol} \mathrm{~L}^{-1}\right)$ and $\mathrm{MnCl}_{2}\left(0.1 \mathrm{~mol} \mathrm{~L}^{-1}\right)$. Then, $100 \mu \mathrm{L}$ of rabbit erythrocytes at $2 \%$ were added to the mixture and incubed at $37^{\circ} \mathrm{C}$ for $30 \mathrm{~min}$, exposed to room temperature for $30 \mathrm{~min}$. The tubes were centrifuged at $8,000 \mathrm{x} \mathrm{g}$ and analyzed for the presence of erythrocytes agglutination. Lectin concentration was expressed as hemagglutinanting units $\mathrm{g}^{-1}$ of the flour (HU) (Moreira and Perrone, 1977).

\section{Phenolic compounds \\ Concentration of total phenols}

The determination of phenolic compounds in the samples was performed according to Price and Butler (1977). The phenolic concentration in flour was determined by a standard curve, which was obtained by linear regression (correlation 
coefficient of 0.99979 and standard deviation of 0.0060). Catechol was used as standard compound for the standard curve.

\section{Presence of tannins}

The analysis of total tannins in the extracts was made according to Hagerman and Butler
(1978, 1989). Tannin concentration in the samples was measured through a standard curve obtained by polynomial regression (correlation coefficient of 0.99946 and standard deviation of 0.025). Tannic acid was used as standard compound for the standard curve.

Table 2 - Elemental analysis of seeds from plant species evaluated*.

\begin{tabular}{lrrrrc}
\hline \multicolumn{1}{c}{ Species } & Hum. & Ashes & Protein & Lipids & Carb. \\
\hline Araticum & 4,80 & 2,27 & 16,33 & 35,24 & 41,46 \\
Vinhático & 0,23 & 4,26 & 24,29 & 4,46 & 67,06 \\
Jatobá & 10,04 & 2,34 & 10,06 & 12,54 & 65,02 \\
Maminha de porca & 13,97 & 5,66 & 6,56 & 17,73 & 56,08 \\
Pau jangada & 5,75 & 5,53 & 12,10 & 22,21 & 54,41 \\
Bacupari & 13,27 & 2,30 & 7,44 & 14,16 & 62,83 \\
Carvoeiro & 1,01 & 5,54 & 32,49 & 9,84 & 51,12 \\
\hline
\end{tabular}

* data expressed in percentage

Hum. - humidity; Carb. - Carbohydrates

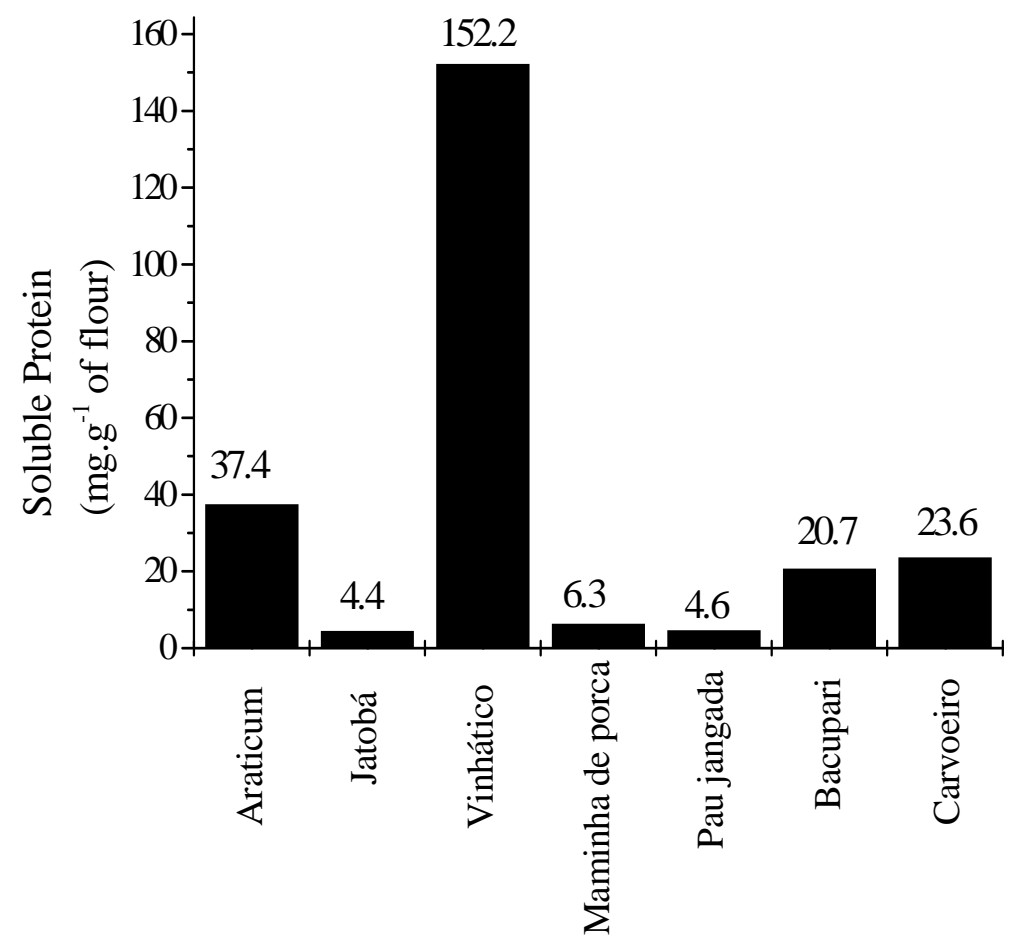

Figure 1 - Concentration of soluble protein ( $\mathrm{mg} \mathrm{g}^{-1}$ of flour). 


\section{RESULTS AND DISCUSSION}

Table 2 shows the results obtained through elemental analysis. All seeds had high carbohydrate concentration (above 41\%). Considerable amounts of proteins (up to $32.49 \%$ in carvoeiro) and lipids (35.24\% in araticum) were detected, showing that these seeds have high potential for extraction of these compounds. The ash content presented high variability (from 2.3\% to $5.7 \%$ ) among the studied species, as well the humidity content (from 0.2 to $14.0 \%$ ). The knowledge of humidity and carbohydrate content are very useful to determine the best storage conditions for these seeds. The highest concentration of soluble protein (Fig. 1) was found in vinhático, with $152.2 \mathrm{mgP} \mathrm{g}^{-1}$ of flour. The total protein content of vinhático was very high compared with those specifically tested in this work (lectins and enzymes). This result is inconvenient for protein purification purposes, because of the number of steps that could be involved in the elimination the undesirable proteins. Nevertheless, the inhibitor content was very high ( up to $20 \%$ of total soluble protein). This was higher then those from leguminous family (Campos and Xavier-Filho, 1987). The use of these seeds as alimentary source of protein needed normal traditional cooking procedures, due to high concentration of trypsin inhibitor in the seeds (Xavier-Filho and Ventura, 1988). The remaining seeds of the tested plants had much lower values of soluble proteins (about 10 times lower). Proteolitic activity (caseinolitic) of the extracts was higher in carvoeiro (Table 3), making this plant a promising source for extraction of this class of enzymes. Besides, no inhibitory activity was detected in the extract of this seed (Fig. 2). This finding indicate their possible use in nutrition. Carvoeiro also presented the highest value of phenols.

In seeds of jatobá, proteolitic activity was the second in magnitude (Table 3). Nevertheless, seeds of this species also presented the highest concentration of protease inhibitors (Fig. 2). The finding of protease inhibitors in this plant permit us to speculate that proteolitic enzyme content is higher than that measured because the enzyme may be inhibited during the extraction process. Moreover, the highest peroxidase activity was found in jatobá. High concentrations of these enzymes family were encountered in Pisum sativum (Halpin et al..1989) and up to four times higher in Opuntia ficus indica (Padiglia et al. 1995). Jatobá also presented the highest amount of tannins (Table 4), relative to the total of phenols (42.808 mg tannin mg of phenol $^{-1}$ ).

Hemagglutinanting activity was detected only in araticum (1013.3 HU g-1 of flour). These seeds have a great biotechnological potential due to its high content of lectins (Martínez and Córdoba, 2000). Besides jatobá, the enzyme inhibitors were also found at high concentrations in vinhático and in maminha de porca (Fig. 2).

Table 3 - Proteolitic activity (Caseinolitic) of gross extracts

\begin{tabular}{l|r|r}
\multicolumn{1}{c}{ Species } & EU g $^{-1}$ flour & Specific activity $\left(\mathbf{E U ~ \mathbf { ~ g ~ } ^ { - 1 }}\right.$ protein) \\
\hline Araticum & 6.912 & 0.185 \\
Jatobá & 497.000 & 113.470 \\
Vinhático & 87.400 & 0.574 \\
Maminha de porca & 107.800 & 17.212 \\
Pau jangada & 138.875 & 30.256 \\
Bacupari & 14.500 & 0.702 \\
Carvoeiro & $196,160.0$ & $8,311.864$ \\
\hline
\end{tabular}

Table 4 - Values of total concentration of phenols and tannins from gross extracts.

\begin{tabular}{|c|c|c|c|}
\hline Species & $\begin{array}{c}\text { Phenols } \\
\mathrm{mg} \mathrm{g}^{-1} \text { of flour }\end{array}$ & $\begin{array}{c}\text { Tannins } \\
\mathrm{mg} \mathrm{g}^{-1} \text { of flour }\end{array}$ & $\begin{array}{c}\text { mg tannins } \text { mg }^{-1} \text { of } \\
\text { phenols }\end{array}$ \\
\hline Araticum & 5.963 & 1.000 & 0.168 \\
\hline Vinhático & 0.807 & 0.299 & 0.370 \\
\hline Jatobá & 0.568 & 3.985 & 7.016 \\
\hline Maminha de porca & 0.052 & 0.211 & 4.058 \\
\hline Pau jangada & 0.227 & 0.300 & 1.322 \\
\hline Bacupari & 3.219 & 1.747 & 0.543 \\
\hline Carvoeiro & 27.585 & 2.268 & 0.082 \\
\hline
\end{tabular}




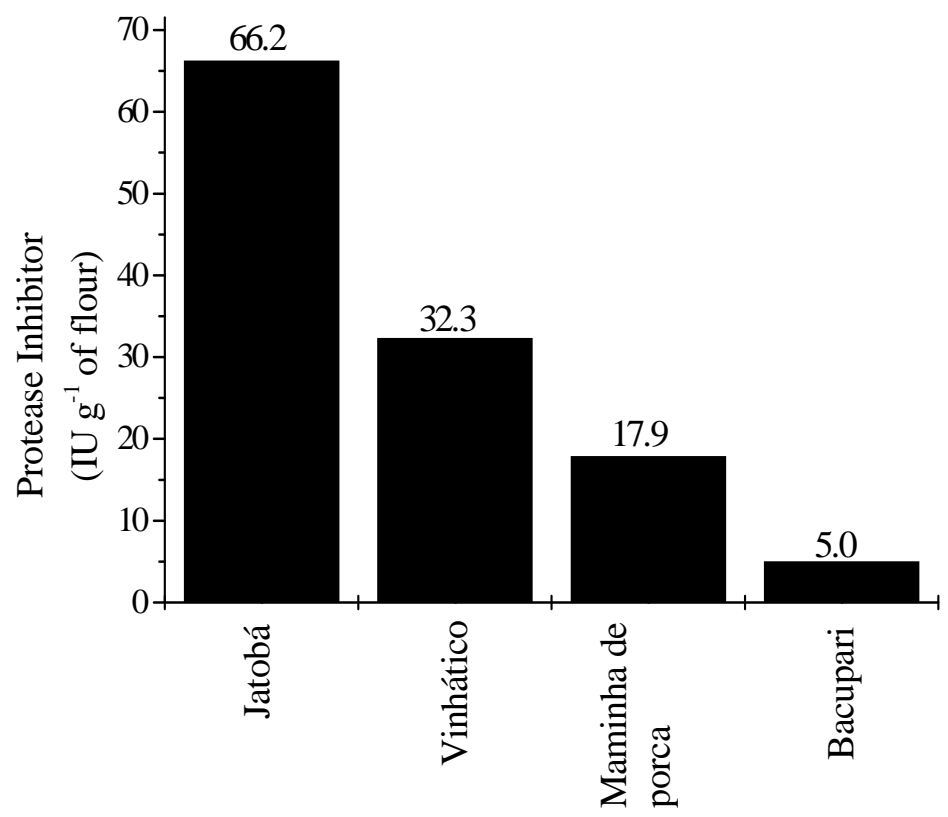

Figure 2 - Determination of protease inhibitor on extracts (IU g $\mathrm{g}^{-1}$ of flour).

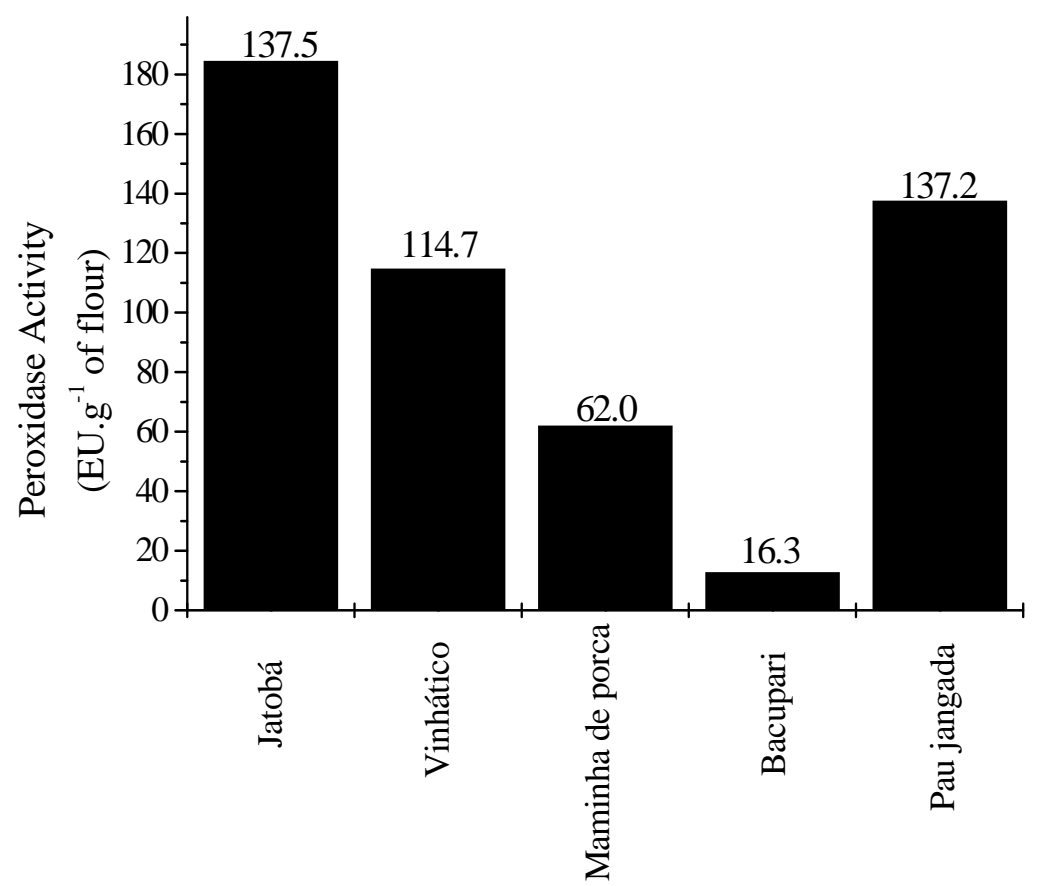

Figure 3 - Peroxidase activity (EU g ${ }^{-1}$ of flour). 


\section{CONCLUSIONS}

Seeds from the plants evaluated in this study had a high potential for extraction of several important components, relevant to the food sector that could be of large utility in the industries. Based on the results presented in this paper, it was possible to observe a large variation in the protein profile of the seeds. Plants such as jatobá, vinhático and carvoeiro, with high level of enzymatic activity, revealed a great potential to be explored. The use of these plants and their enzymes in the food industry could lead to the development of new products from traditional raw materials, and to the concentration of new sources of food. The concentration of trypsin inhibitor presented toxic levels in vinhático and therefore, cooking would be necessary for this plant. Phenolic compounds of all studied seeds were not significant compared to toxic values found in the literature. Some of the species such as carvoeiro and jatobá must be further studied to determine the degree of showed toxicity, because of its high concentration of tannins. Bacupari, carvoeiro and araticum, due to their high concentration of phenols, could be used in biotechnology, among other applications.

\section{RESUMO}

O Cerrado é constituído por inúmeras espécies vegetais com potencial econômico, as quais são utilizadas para os mais variados fins, como medicinal e nutricional. O objetivo deste trabalho foi analisar e quantificar a presença de atividade enzimática de peroxidases e proteases e fatores antinutricionais, como lectinas e inibidores de proteases, além de polifenóis e taninos em algumas espécies nativas do Cerrado. O material vegetal utilizado foram sementes de Annona crassiflora Mart. (araticum), Hymenaea courbaril L. var. courbaril (jatobá), Plathymenia reticulata Benth. (vinhático), Zanthoxylum rhoifolium Lam. (maminha de porca), Apeiba tibourbou Aubl. (pau jangada), Salacia crassiflora (Mart.) G. Don. (bacupari) e Sclerolobium paniculatum Vog. (carvoeiro), coletadas na cidade de Goiânia e municípios de Jataí e Caldas Novas, estado de Goiás. O uso potencial destas plantas e suas enzimas na indústria de alimentos, poderia resultar em aplicações ao aparecimento de novos produtos a partir das matérias-primas tradicionais, além do uso de novas fontes de alimentos.

\section{REFERENCES}

Almeida, S. P.; Proença, C. E. B.; Sano, S. M. and Ribeiro, J. F. (1998), Cerrado: espécies vegetais úteis. Planaltina : EMBRAPA-CPAC.

Arnon, R. (1970), Papain. In: Methods in enzymology. New York : Academic Press. v. 19. pp. 226-234.

Bradford, M. (1976), A rapid and sensitive method for the quantification of microgram quantities of proteins utilizing the principle of protein dye binding. Anal. Biochem., 72, 248-254.

Campos, F. A. P. and Xavier-Filho, J. (1987), Trypsin inhibitors in seeds of Canavalia brasiliensis Mart. Rev. brasil. Bot., 10, 95-98.

Drumond, M. A. (1982), Potencialidade das essências nativas do trópico semi-árido. Silvicultura em São Paulo, 16, 766-781.

Hagerman, A. E. and Butler, L. G. (1989), Choosing appropriate methods and standards for assaying tannins. J. Chem. Ecol., 15, 1795-1810.

Hagerman, A. E. and Butler, L. G. (1978), Protein precipitation method for the quantitative determination of tannins. J. Agr. Food Chem., 26, 809-812.

Halpin, B.; Pressey, R.; Jen, J. and Mondy, N. (1989), Purification and Characterization of Peroxidase Isoenzymes from Green Peas (Pisum sativum). J. Food Sci., 54, 644-649.

Henry, R. J.; Cannon, D. C. and Winkelman, J. (1974), Clinical Chemistry: principles and techniques. 2. ed, New York : Harper and Row Publishers Inc. pp. 1288.

Laurena, A. C.; Revilleza, J. R. and Mendoza, E. M. T. (1994), Polyphenols, Phytate, Cyanogenic Glycosides, and Trypsin Inhibitor Activity of Several Philippine Indigeous Food Legumes. J. Food Comp. Anal., 7, 194-202.

Moreira, R. A. and Perrone, J. C. (1977), Purification and partial characterization of a lectin from Phaseolus vulgaris. Plant Physiol., 59, 783-787.

Martínez, M.and Córdoba, F. (2000), Isolation of fully active and stable corn coleoptile lectins. Prep. Biochem. and Biotechnol., 30, 199-208.

Padiglia, A.; Cruciani, E.; Pazzaglia, G.; Medda, R., and Floris, G. (1995), Purification and characterization of Opuntia peroxidase. Phytochemistry, 38, 295-297.

Price, M. L. and Butler, L. G. (1977), Rapid visual estimulation and spectrophotometric determination of tannin content of sorghum grain. J. Agr. Food Chem., 25, 1268-1273. 
Silva, K.F.F.; Lima, C.S.; Do Val, R. and Xavier-Filho, J. (1995), Cysteine proteinase inhibitors from seeds of Adenanthera pavonina L. Rev. Brasil. Bot., 18, 137-141.

Xavier-Filho, J. And Ventura, M. M. (1988), Trypsin Inhibitors in Cowpea: A Review. Comments Agric. and Food Chem., 1, 239-264.

Received: March 21, 2002; Revised: July 24, 2002; Accepted: November 18, 2002. 